\title{
Operational Strategies of Online Food Delivery Businesses in Camarines Norte, Philippines
}

\author{
Harold D. Abasolo, MBA ${ }^{1}$, Gehana D. Lamug, DBA ${ }^{2}$ \\ ${ }^{1}$ Mabini Colleges, Inc. \\ ${ }^{2}$ Camarines Norte State College
}

\begin{abstract}
This research determined the operational strategies of online food delivery businesses in Camarines Norte, Philippines. It assessed the profile of the online food delivery businesses in terms of number of riders, initial capitalization, form of business organization, commonly used digital platform and average weekly deliveries; the operational strategies being implemented and the problems encountered on the aspects of resources and processes. Findings revealed that majority of online food delivery businesses have 11 to 15 riders, under sole proprietorship, uses social media platform, with 201 and above weekly deliveries. The operational strategies of online food delivery businesses include: monitoring of riders' performances, use of cellular phones, desktop, tablet and laptop for monitoring customer needs; optimizing marketing budget through utilization of low-cost marketing campaigns and promotions; promotion using various social media platforms; and updating customers with their transactions from time-to-time via chat or Short Message Service (SMS). The problems encountered by online food delivery businesses are shortage of available riders during peak hours and threat of new entrants. The study recommended for food delivery business owners to revisit the human resource plans and create operations manual to provide clear guidelines and processes in implementing their operational strategies which are significant to their daily operations.
\end{abstract}

KEYWORDS: Online Food Delivery Businesses, Operational Strategies, Resources and Processes

\section{INTRODUCTION}

In a global perspective, businesses aim to remain competitive and sustainable that is why they continue to evolve and adapt to the changing business landscape. One of the ways to maintain sustainability is to strengthen their operational strategies. According to Raounas (2021) operational strategies involve crafting and delineating a firm's business strategy and developing strategic activities and operational plans, aiming at enabling customer to successfully enforce overall strategy for their businesses. In addition, food delivery businesses, just like other types of enterprises, operate using sets of strategies and their operational strategies are the drivers of a company's success. It is a part of a business overall strategy, and both are crucial for an organization to compete in a dynamic business environment (Eby, 2017).

The trend nowadays are availing delivery services to get things done promptly and expeditiously. These are businesses comprised of a team of employees that deliver work or assist in completing task for the benefit of its customers (Hill, 2019). In the Philippines, the operations of online delivery businesses is supported and governed by the Republic Act No. 8792 also known as an act providing for the recognition and use of electronic commercial and non-commercial transactions, penalties for unlawful use and other purposes. It is where the state acknowledges the indispensable role of information and communications technology (ICT) in the development of the nation; the topmost responsibility of the private sector in contributing investments and services in ICT; the demand to create, with suitable training programs and organizational policy changes, human resources for the information age, a labor force proficient in the use of ICT and a population capable of operating and employing electronic appliances and computers; to guarantee system security, connectivity and neutrality of technology for the national benefit.

In Camarines Norte, only few online food delivery services were actively operating even before the COVID-19 outbreak. The very first delivery service is the Lokal Delivery Express offering services mainly focusing on food delivery and running other errands for customers. Then, Purple Box Express opened its business using the same concept and also to minimize the gap between the demand and supply for the said services. But when the demand for these services rose, its population inflated from three to 


\section{International Journal of Current Science Research and Review}

ISSN: 2581-8341

Volume 04 Issue 08 August 2021

DOI: 10.47191/ijcsrr/V4-i8-14, Impact Factor: 5.825

almost twenty different online food delivery businesses operating in the area. Other delivery businesses that followed and offered the same services such as Pilivery Graces, Daet Entrega, Daet Cu Tie Delivery, Daet Pabili, Daet Pabakal, Go Papa, among others.

The increasing number of competitors triggered each of them to focus on the marketing strategies to maintain their customers and attract more. The surge on demand during peak hours forced them to decline orders of some customers thereby compelling them to transfer to other delivery businesses. These are just among the problems that they experience as they continue their business operations. This has caused each of them to struggle with their operational strategies in order to stay in the industry. Some of them had lesser customers due to a high difference between delivery fees (P45 versus P30). Others have a more active social media account as their main promotional platform. They also have to compete with each other on the favors of restaurants and establishments based on the number of deliveries made. These situations led this research to determine their operational strategies to be able to provide additional literature on their business existence in the new normal.

\section{METHODOLOGY}

The study used the descriptive method of research. It used quantitative approach because it described the profile of the respondents, the operational strategies implemented, and problems encountered by the online food delivery businesses. The respondents were purposively selected and they comprised of the owners of the 30 existing registered online food delivery businesses operating in Daet, Camarines Norte based on the list requested from Local Government Unit (LGU) of the same municipality in 2021. Total enumeration was used in determining the respondents. All the registered online food delivery businesses were sent with a copy of the questionnaire but only 24 or 80 percent retrieval was generated and six respondents or 20 percent refused to answer the survey.

The frequency distribution technique was used in determining the profile of the respondents of the study. Frequency count measured the frequency of the respondents' answers and the most commonly occurring aspects in the study. The weighted mean, on the other hand, was used in assessing the operational strategies of the online food delivery businesses. For determining the problems that online food delivery businesses commonly encountered, ranking was used.

\section{RESULTS AND DISCUSSIONS}

Tables 1 to 6 present the profile of the respondents as to number of riders, initial capitalization, form of business organization, commonly used digital platform and average weekly deliveries.

Number of Riders. Table 1 presents the profile of respondents based on the number of riders. Results show that majority of online food delivery businesses in Daet, Camarines Norte has 11 to 15 riders comprising of 10 respondents or 41.66 percent while the lowest has more than 15 riders or 4.17 percent.

Table 1. Profile of Respondents Based on Number of Riders

\begin{tabular}{|c|c|c|}
\hline Number of Riders & Frequency & Percentage (\%) \\
\hline 5 and below & 5 & 20.83 \\
\hline $6-10$ & 7 & 29.17 \\
\hline $11-15$ & 10 & 41.66 \\
\hline $16-20$ & 1 & 4.17 \\
\hline 21 and above & 1 & 4.17 \\
\hline Total & 24 & 100.00 \\
\hline
\end{tabular}

The data implies that delivery services usually have 11 to 15 riders to run their operations daily. Ideally, it is the number of riders that an online food delivery in the province require for its normal or day-to-day business operations. Online food ordering leads the chart of online orders and this produces millions of food delivery employees (Mukhopadhyay and Chatwin, 2021).

Initial Capitalization. Table 2 shows that the highest initial capitalization by delivery services belongs to 13 respondents which started with an initial capital of below P50,000 with 54.17 percent while the lowest is only one respondent who had an initial capital of more than $\mathrm{P} 100,000$ with 4.16 percent. 


\section{International Journal of Current Science Research and Review}

ISSN: 2581-8341

Volume 04 Issue 08 August 2021

DOI: 10.47191/ijcsrr/V4-i8-14, Impact Factor: 5.825

Table 2. Profile of Respondents based on Initial Capitalization

\begin{tabular}{clc}
\hline \hline Initial Capitalization & Frequency Count & Percentage $(\%)$ \\
\hline Below P50,000 & 13 & 54.17 \\
P50,001 - P100,000 & 10 & 41.67 \\
P100,001 and above & 1 & 4.16 \\
Total & 24 & 100.00 \\
\hline \hline
\end{tabular}

The result reveals that the majority of the delivery services have initial capital of below P50,000 which means that an online food delivery business is an easy service business to start with. This implies that the business needs a small start-up capital to run with only some needed tools and equipment for mandatory purchase such as delivery boxes, office laptop and internet connection. The motorcycle, cellular phones, helmet, among others are commonly owned by the delivery riders and are part of the criteria in terms of hiring them, as such, covered expenses are maintenance and fuel expenses. Interestingly, there are online delivery business which are located in the owner's residence, this allowed them to save for rent expense.

Form of Business Organization. Table 3 presents the form of business organization used by the online delivery businesses in the province. Majority of the delivery businesses or 19 respondents with 79.17 percent formed their business under sole proprietorship while five respondents with 20.83 percent applied for partnership form of business organization.

Table 3. Profile of Respondents in terms of Business Organization

\begin{tabular}{cll}
\hline \hline Form of Business Organization & Frequency & Percentage (\%) \\
\hline Sole Proprietorship & 19 & 79.17 \\
Partnership & 5 & 20.83 \\
Total & 24 & 100.00 \\
\hline \hline
\end{tabular}

The results show that majority of online food delivery businesses are owned by individuals or sole proprietors since the needed capitalization to start the operation is minimal and easy to set up. Also, the owners can freely and promptly decide on matters pertaining to its day-to-day operations as a sole decision-maker. This is supported by the result of Table 2 where the initial capitalization that the delivery services provided to start the business is below P50,000.

Commonly Used Digital Platform. The results presented in Table 4 shows that all the 24 respondents or 100 percent use social media platforms like Facebook, Twitter, Instagram and LinkedIn in their business operations while no one uses knowledge platform like Quora or Yahoo! Answers, media sharing platform such as Youtube, Spotify and Vimeo and service-oriented platforms such as Airbnb or Grubhub.

Table 4. Profile of Respondents in terms of Commonly Used Digital Platform

\begin{tabular}{lll}
\hline \hline Digital Platforms & Frequency Count & Percentage (\%) \\
\hline Social Media Platforms & 24 & 100.0 \\
& & \\
Knowledge Platforms & 0 & 0.0 \\
Media Sharing Platforms & 0 & 0.0 \\
Service-Oriented Platforms & 0 & 0.0 \\
Total & 24 & 100.0 \\
\hline \hline
\end{tabular}

The findings revealed that all delivery businesses are using social media platforms to be able to promote the business, update product offerings, and gain customers as well as sales. This implies that social media platforms are the most accessible platforms for this kind of business both for the delivery service operators and the customers. Social media can reach millions of people all around the world and by using this as their main platform, they can easily reach their target customers using Facebook, 
ISSN: 2581-8341

Volume 04 Issue 08 August 2021

DOI: 10.47191/ijcsrr/V4-i8-14, Impact Factor: 5.825

Twitter and Instagram, among others. These are the preferred online platform as it is free and manageable while reaching wider customer base.

Average Weekly Deliveries. This table shows the average weekly deliveries made by the online food delivery businesses. Results show that the 41.67 percent have average weekly deliveries of 201 and above while 25 percent have 100 and below average weekly deliveries.

Table 5. Profile of Respondents in terms of Average Weekly Deliveries

\begin{tabular}{cll}
\hline \hline Average Weekly Transaction & Frequency Count & Percentage (\%) \\
\hline 100 and below & 6 & 25.00 \\
$101-200$ & 8 & 33.33 \\
201 and above & 10 & 41.67 \\
Total & 24 & 100.00 \\
\hline \hline
\end{tabular}

Some of the delivery services have 201 and above average weekly deliveries. The data can be attributed to the increasing demand for online food delivery businesses in Camarines Norte wherein the majority of customers shifted to online food ordering. These provided them convenience and maximize their time as well as they avoided long queues and hassles while transacting orders. The result is supported by Lattanzi (2020) which found out that the online food industry continues to grow around the world during the last five years emphasizing that millions of customers now choose that their groceries and meals delivered instead of doing personal shopping.

\section{Operational Strategies of Online Food Delivery Businesses in terms of Human, Material and Financial Resources}

Tables 6 to 8 present the operational strategies of online food delivery businesses in Camarines Norte in terms of human, material and financial resources.

Human Resources. Table 6 illustrates the operational strategies of online food delivery businesses in terms of human resources. Monitoring of riders' performances gained the highest rating of 4.46 and using outside services had a lowest weighted mean of 3.58 which is interpreted as often.

Table 6. Operational Strategies of Online Food Delivery Businesses in terms of Human Resources

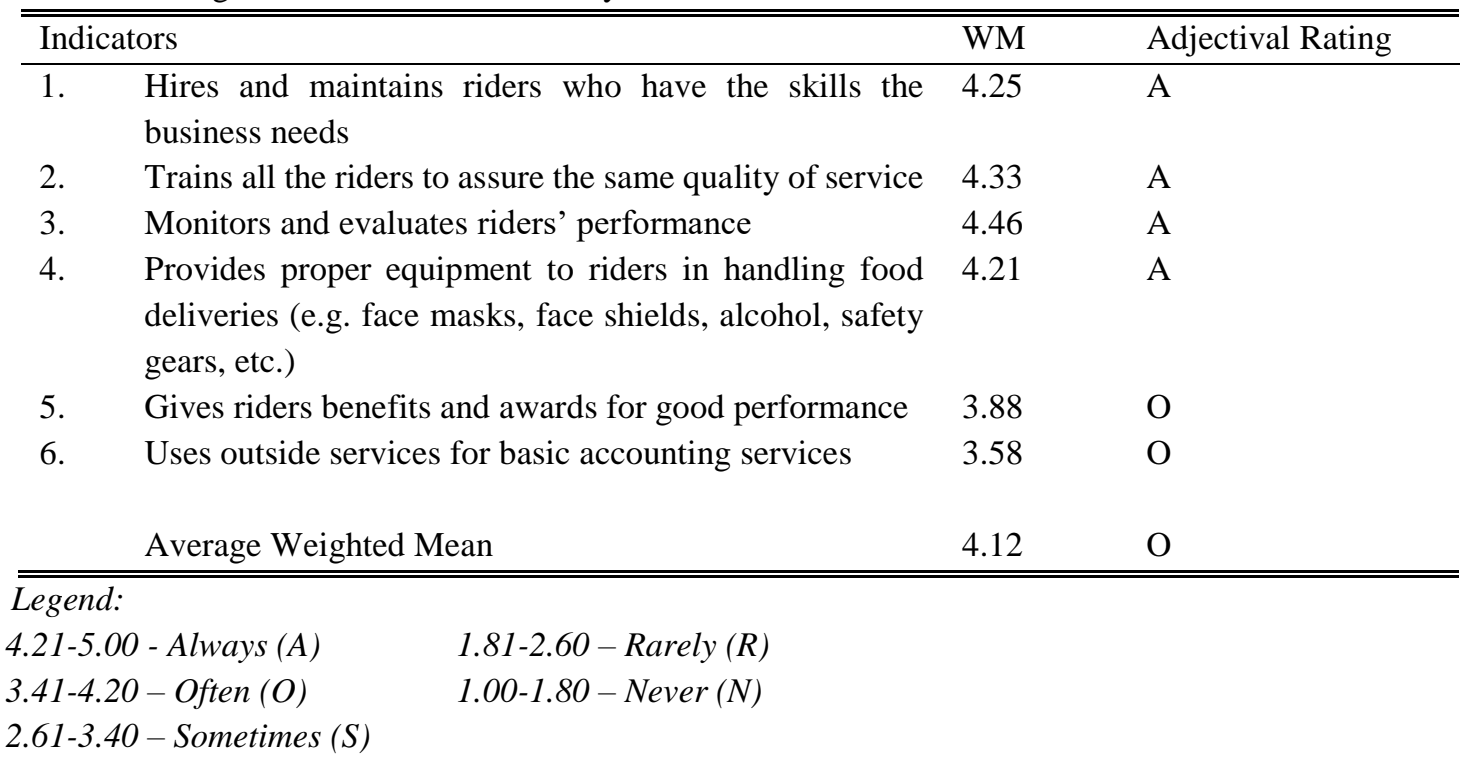


ISSN: 2581-8341

Volume 04 Issue 08 August 2021

DOI: 10.47191/ijcsrr/V4-i8-14, Impact Factor: 5.825

The results signified that online food delivery owners monitor and evaluate riders' performances as their primary operational strategy in the human resource aspect. It implies that it is one of their ways to ensure quality delivery services are being performed by riders. Regular monitoring and evaluation by the owners also help the riders better understand what is expected of them. Similarly, it improves communication between management and employees and it gives employee proper guidance in terms of work performance. This is done by the delivery owners through constant communication with riders and proper coordination with orders. It is substantiated by the study of Alarcon (2017) where it reveals that employees' evaluations serves different purposes and is meant to enhance their performance and the company culture.

Material Resources. Table 7 shows the operational strategies of online food delivery businesses in terms of material resources. In general, the respondents are often implementing the given indicators in their daily operations with an average weighted mean of 4.00. Specifically, the most performed operational strategy for material resources is the use of cellular phones, desktop, tablet and laptop for monitoring customer needs with the weighted mean of 4.96 and interpreted as always implemented. While the indicator that got the lowest weighted mean is the use of tricycle or large-capacity vehicles with only 3.08 and is also interpreted as sometimes implemented.

Table 7. Operational Strategies of Online Delivery Businesses in terms of Material Resources

\begin{tabular}{|c|c|c|c|}
\hline \multicolumn{2}{|c|}{ Indicators } & \multirow{2}{*}{$\begin{array}{l}\mathrm{WM} \\
4.88\end{array}$} & \multirow{2}{*}{$\begin{array}{l}\text { Adjectival Rating } \\
\text { A }\end{array}$} \\
\hline 1. & $\begin{array}{l}\text { Runs the business out of a home office, basement or } \\
\text { garage to lessen cost }\end{array}$ & & \\
\hline 2. & $\begin{array}{l}\text { Purchases high-quality, made-to-order or customized } \\
\text { delivery box or motorcycle box }\end{array}$ & 3.33 & S \\
\hline 3. & $\begin{array}{l}\text { Ensures that motorcycles used by riders are } \\
\text { constantly performing maintenance check-up }\end{array}$ & 4.58 & A \\
\hline 4. & $\begin{array}{l}\text { Utilizes cellular phones, desktop, tablet and laptop } \\
\text { for monitoring customer needs }\end{array}$ & 4.96 & A \\
\hline 5. & $\begin{array}{l}\text { Uses tricycle or large-capacity vehicles for bulk } \\
\text { orders or heavy equipment deliveries }\end{array}$ & 3.08 & S \\
\hline \multirow[t]{2}{*}{6.} & $\begin{array}{l}\text { Designs variety of contingency plans that can help } \\
\text { address potential difficulties such as procurement } \\
\text { options, missed connections en route, vehicle } \\
\text { breakdowns, etc. }\end{array}$ & 3.17 & $S$ \\
\hline & Average Weighted Mean & 4.00 & $\mathrm{O}$ \\
\hline \multicolumn{4}{|c|}{ Legend: } \\
\hline & 4.21-5.00 - Always (A) & & \\
\hline & $\begin{array}{l}3.41-4.20-\text { Often }(O) \\
2.61-3.40-\text { Sometimes }(S)\end{array}$ & & \\
\hline
\end{tabular}

The results presented above mean that the most important material resource for online food delivery business is the use of gadgets such as cellular phones, laptops, desktops or tablets. It is because these gadgets serve as the medium of communication between them and the customers. Accessing social media can only be possible if these gadgets were available as these are one of the staples in online business. This finding is associated in Table 4 which is the commonly used digital platform by delivery services is social media platform for promoting business and reaching customers. The result was parallel with the study of Suttle (2017), where it revealed that anyone can put up a small service business with minimum facilities, beyond a basic office set up and dependable transportation.

Financial Resources. Table 8 shows the operational strategies of delivery businesses in terms of financial resources. Overall, results shows that online food delivery businesses often perform operational strategies for financial resources as evidenced by the 


\section{International Journal of Current Science Research and Review}

ISSN: 2581-8341

Volume 04 Issue 08 August 2021

DOI: 10.47191/ijcsrr/V4-i8-14, Impact Factor: 5.825

average weighted mean of 3.98. Specifically, optimizing marketing budget through utilization of low-cost marketing campaigns and promotions got the highest weighted mean of 4.75 while the least implemented operational strategy under financial resources is the preparation of monthly budget plan with a weighted mean of 3.33 interpreted as sometimes.

Table 8. Operational Strategies of Online Food Delivery Businesses in terms of Financial Resources

\begin{tabular}{lll}
\hline \hline Indicators & WM & Adjectival Rating \\
\hline 1. $\quad \begin{array}{l}\text { Keeps at least } 10 \% \text { of profits as retained earnings thereby } \\
\text { increasing owner's equity }\end{array}$ & 4.17 & $\mathrm{O}$ \\
2. $\quad \begin{array}{l}\text { Allots at least } 10 \% \text { of working capital for research and } \\
\text { development, marketing programs, or infrastructure upgrade }\end{array}$ & 3.96 & $\mathrm{O}$ \\
3. $\begin{array}{l}\text { Performs daily recording of finances using journal, ledger and } \\
\text { other books of accounts }\end{array}$ & 3.88 & $\mathrm{O}$ \\
4. $\quad \begin{array}{l}\text { Prepares monthly budget plan } \\
\text { 5. Prepares monthly financial statements to keep track of the }\end{array}$ & 3.79 & $\mathrm{~S}$ \\
$\quad \begin{array}{l}\text { finances of the business } \\
\text { Maximizes marketing budget through utilization of low-cost }\end{array}$ & 4.75 & $\mathrm{~A}$ \\
$\quad \begin{array}{l}\text { marketing campaigns and promotions } \\
\text { Average Weighted Mean }\end{array}$ & 3.98 & $\mathrm{O}$ \\
\hline \hline
\end{tabular}

Legend:

$\begin{array}{ll}\text { 4.21-5.00 - Always }(A) & 1.81-2.60-\operatorname{Rarely}(R) \\ 3.41-4.20-\text { Often }(O) & 1.00-1.80-\operatorname{Never}(N) \\ 2.61-3.40-\text { Sometimes }(S) & \end{array}$

The table reveals that online delivery businesses always maximize marketing budget through utilization of low-cost marketing campaigns and promotions. The results imply that they maximize allocated marketing budgets through budget-friendly promotional strategies and campaigns such as boosting marketing on social media posts, providing items for their raffles and providing giveaways or souvenir to the customers. These can be seen through their use of social media by creating the business' own Facebook page for free and attracting as many followers and friends to increase awareness and ultimately convert them into customers. Some promotional strategies being employed by delivery businesses include reward points, freebies and online promotions such as mugs, shirts, raffles, among others to entice customers to purchase their services. It is supported by the study conducted by Upadhayay et al. (2020) which found that nowadays businesses use modern marketing like social media platforms, email, internet advertisements and affiliate marketing.

\section{Problems Encountered by the Online Food Delivery Businesses in terms of Resources and Processes}

Tables 9 and 10 exhibit the problems encountered by the online food delivery businesses in terms of resources and processes.

Resources. Table 9 presents the problems encountered by the online food delivery businesses in terms of resources. The results indicated that the shortage of available riders during peak hours ranked first with a frequency of 23. Shorter useful life of delivery equipment and failure to track cash inflows and outflows both with a frequency of three and the misallocation of funds or capital with only a frequency count of one were the lowest indicators.

Table 9. Problems Encountered by Online Food Delivery Businesses in terms of Resources

\begin{tabular}{lllc}
\hline \hline & Indicators & Frequency & Ranking \\
\hline 1. & Difficulty in maintaining skilled riders & 8 & 8 \\
2. & Risks on health, safety and security of riders & 15 & 4 \\
3. & Lack of disciplined and customer-oriented riders & 11 & 6.5
\end{tabular}




\section{International Journal of Current Science Research and Review}

ISSN: 2581-8341

Volume 04 Issue 08 August 2021

DOI: 10.47191/ijcsrr/V4-i8-14, Impact Factor: 5.825

\begin{tabular}{lllc} 
4. & Customer complaints on rider's behavior or performance & 13 & 5 \\
5. & $\begin{array}{l}\text { Lacking criteria on monitoring performance and productivity } \\
\text { of riders }\end{array}$ & 6 & 9 \\
6. & Shortage of available riders during peak hours & 23 & 1 \\
7. & Shorter useful life of delivery equipment & 3 & 13.5 \\
8. & Incidences of motorcycle accidents & 5 & 11 \\
9. & $\begin{array}{l}\text { Unstable internet connection affecting the communication } \\
\text { with customers and partner establishments }\end{array}$ & 22 & 2 \\
10. & Incapacity to accept bulk orders/large orders & 16 & 3 \\
11. & Limited materials and tools used in processing orders & 5 & 11 \\
12. & Failure to regularly prepare budget plan & 11 & 6.5 \\
13. & Misallocation of funds or capital & 1 & 15 \\
14. & Failure to track cash inflows and outflows of the business & 3 & 13.5 \\
15. & Increased business expenses & 5 & 11 \\
\hline \hline
\end{tabular}

The topmost problem encountered by online food delivery businesses in terms of resources is the shortage of riders during peak hours. This is a result of having a small number of delivery riders employed by the business. On the average, they only have 11 to 15 riders who have to run errands of customers in the fastest time possible particularly during lunchtime, snacks and dinner as reflected in the result of Table 1. It is backed up by the findings of Table 5 where some of the delivery services have 201 and above average weekly deliveries. This can also be attributed to the limited number of delivery riders by the delivery businesses wherein they difficulty meeting the surge in demand during peak hours. This is symmetrical to the findings which enumerated aspects that should be considered when building a strategy for online businesses and that regarded the allocation of additional support personnel to handle the upsurge of orders (Emmer, 2020).

Processes. Table 10 problems encountered by online delivery services in terms of marketing processes were presented. Topping the list is the threat of new entrants with a frequency of 21 followed by wavering customer loyalty and incapacity to handle high customer demands in the second rank both gaining a frequency of 20. The least problems which are ranked 14.5 are inconsistency of service quality provided to the customers and erroneous liquidation of delivery riders.

Table 10. Problems Encountered by Online Food Delivery Businesses in terms of Processes

\begin{tabular}{llcl}
\hline \hline & Indicators & Frequency & Ranking \\
\hline 1. & Competitors copying social media promotional strategies & 16 & 4.5 \\
2. & Wavering customer loyalty & 20 & 2.5 \\
3. & Unmet customer satisfaction & 9 & 7.5 \\
4. & Threat of new entrants affecting the market share of the business & 21 & 1 \\
5. & Limited areas covered or being reached by riders & 8 & 9 \\
6. & Bogus or prank buyers & 16 & 4.5 \\
7. & Cancelled orders of customers & 9 & 7.5 \\
8. & Incapacity to handle high customer demands & 20 & 2.5 \\
9. & Increased risks associated with product safety & 5 & 10.5 \\
10. & Inefficient order management system & 3 & 12.5 \\
11. & Inconsistency of service quality provided to customers & 1 & 14.5 \\
12. & Limited means to track orders to partner establishment & 5 & 10.5 \\
13. & Erroneous liquidation reports of riders & 1 & 14.5 \\
14. & Equipment breakdowns such as vehicle malfunction, etc. & 3 & 12.5 \\
15. & Difficulty in ensuring the safety of large orders & 10 & 6
\end{tabular}




\section{International Journal of Current Science Research and Review}

ISSN: 2581-8341

Volume 04 Issue 08 August 2021

DOI: 10.47191/ijcsrr/V4-i8-14, Impact Factor: 5.825

The results show that among their most commonly encountered problem is the threat of new entrants affecting the market share of the business. The growth of delivery businesses in Camarines Norte increased from a mere two competing businesses before lockdown due to the spread of COVID 19 in March, 2019 to 30 in 2021 which makes the existing businesses threatened by the increasing number of competitors. When a particular business is thriving, others will put up the same business and thus, will result to increasing competitors and thereby decreasing market share. It is substantiated by the findings about online food delivery businesses wherein it is expected to grow at a compound annual growth rate of 15.4 percent from 2019 to 2025 (Grand View Research, 2019).

\section{CONCLUSIONS}

In the light of the findings of the study, the following conclusions were drawn majority of online food delivery businesses have 11 to 15 riders, under sole proprietorship as the form of business organization, uses social media as a digital platform, with average weekly deliveries which range from 201 and above. In addition, the operational strategies of online food delivery businesses which are always implemented include the following: monitoring of riders' performances, use of cellular phones, desktop, tablet and laptop for monitoring customer needs, optimizing marketing budget through utilization of low-cost marketing campaigns and promotions while the problems encountered by online food delivery businesses are shortage of available riders during peak hours and threat of new entrants. The study recommended for online food delivery business owners to consider revisiting the human resource plans and create operations manual to provide clear guidelines and processes in implementing their operational strategies which are significant to their daily operations.

\section{LITERATURE CITED}

1. Raounas, G. (2021). Operational Strategy. https://home.kpmg/gr/en/home/services/advisory/managementconsulting/business-performance-services/operationalstrategy.html

2. Eby, K. (2017). Operations Strategies: Definition, Process, Plans, Pro Insights.h ttps://www.smartsheet.com/operationsstrategies-definitions-process-planspro-insights

3. Hill, A. (2019). What is A Service Business? https://study.com/academy/lesson/what-is-a-service-business.htm

4. Republic Act No. 8792. (2000). https://www.officialgazette.gov.ph/2000/06/14/ republic-act-no-8792-s-2000/

5. Mukhopadhyay, B. R., \& Chatwin, C. (2021). The Return of Herzberg and Taylor: Understanding the Motivation of Food Delivery Riders for Meituan and Ele. me in the Gig Economy of China. https://www.researchgate.net/profile/ BoidurjoMukhopadhyay/publication/344465380_The_Return_of_Herzberg_and_Taylor_Understanding_the_Motivation _of_Food_Delivery_Riders_for_Meituan_and_Eleme_in_the_Gig_Economy_of_China/links/5f79c3f0299bf1b53e0c319 1/The-Return-of-Herzberg-and-Taylor-Understanding-the-Motivation-of-Food-Delivery-Riders-for-Meituan-and-Elemein-the-Gig-Economy-of-China.pdf

6. Lattanzi, A. (2020). Food delivery platforms revolutionizing the market during COVID-19: Why is regulation lagging behind? https://www.ifis.org/blog/food-delivery-platforms-covid-19

7. Alarcon, J. (2017) 5 Great Qualities of a Delivery Courier Service in the Philippines.ht https://www.lalamove.com/philippines/manila/fil/blog/5-qualities-courier-delivery-service-philippines

8. Suttle, R. (2017) How to start a small business courier service. https://smallbusiness.chron.com/startsmallbusinesscourierservice2224.html

9. Upadhayay, D., Thakkar, H. \& Ghiya, N., (2020) A Study of Impact of Promotion and Marketing Campaigns by Online Food Delivery Service on Buying Behavior of Customer of Ahmedabad. https://ssrn.com/abstract=3637941 or http://dx.doi.org/10.2139/ssrn.3637941

10. Emmer, M. (2020). Developing a business strategy in 10 steps. https://www.vistage.com/researchcenter/businessleadership/strategicplanning/20181105-10-steps-building-best-businessstrategies/ 
International Journal of Current Science Research and Review

ISSN: 2581-8341

Volume 04 Issue 08 August 2021

DOI: 10.47191/ijcsrr/V4-i8-14, Impact Factor: 5.825

IJCSRR @ 2021

www.ijesrr.org

11. Grand View Research. (2019).Online food delivery services market size, share \& trends analysis report by type, by channel type, by payment method, by region, and segment forecast, 2019-2025.https://www. grandviewresearch.com/ industryanalysis/online-food-delivery-services-market

Cite this Article: Harold D. Abasolo, MBA, Gehana D. Lamug, DBA (2021). Operational Strategies of Online Food Delivery Businesses in Camarines Norte, Philippines. International Journal of Current Science Research and Review, 4(8), $974-982$ 